\title{
The effects of market economy and foreign MNE subsidiaries on the convergence and divergence of HRM
}

Article

Accepted Version

Farndale, E., Brewster, C., Ligthart, P. and Poutsma, E. (2017) The effects of market economy and foreign MNE subsidiaries on the convergence and divergence of HRM. Journal of International Business Studies, 48 (9). pp. 1065-1086. ISSN 1478-6990 doi: https://doi.org/10.1057/s41267-017-0094-8 Available at http://centaur.reading.ac.uk/70478/

It is advisable to refer to the publisher's version if you intend to cite from the work. See Guidance on citing.

To link to this article DOI: http://dx.doi.org/10.1057/s41267-017-0094-8

Publisher: Palgrave Macmillan

All outputs in CentAUR are protected by Intellectual Property Rights law, including copyright law. Copyright and IPR is retained by the creators or other copyright holders. Terms and conditions for use of this material are defined in the End User Agreement. 


\section{CentAUR}

Central Archive at the University of Reading

Reading's research outputs online 


\title{
THE EFFECTS OF MARKET ECONOMY AND FOREIGN MNE SUBSIDIARIES ON THE CONVERGENCE AND DIVERGENCE OF HRM
}

\begin{abstract}
This study explores patterns of human resource management (HRM) practices across market economies, and between indigenous firms and foreign MNE subsidiary operations, offering a novel perspective on convergence and divergence. Applying institutional theorizing to improve our understanding of convergence/ divergence as a process and an outcome, data collected from nine countries at three points in time over a decade confirm that convergence and divergence occur to different extents in a non-linear fashion, and vary depending on the area of HRM practice observed. Patterns of adoption and convergence/ divergence are explained through the effect of institutional constraints, which vary between liberal and coordinated market economies, and between indigenous firms and foreign MNE subsidiaries. The study contributes a more graded conceptualization of convergence/ divergence, which reflects the complex dynamic reality of international business.
\end{abstract}




\section{INTRODUCTION}

Multinational enterprises (MNEs) are key contributors to the spread of business practices around the world (Edwards, Sánchez-Magnas, Jalette, Lavelle \& Minbaeva, 2016). However, neo-institutional theory (DiMaggio \& Powell, 1983; Scott, 2001) posits that context will be an important constraint on managerial autonomy over business practices. Human resource management (HRM) is a particular test case, having long been identified as the most 'national' of practices (Rosenzweig \& Nohria, 1994). Does the global drive for convergence on the basis of the most economically effective practices apply to HRM, or do economies with different institutional bases continue to constrain the possibility of convergence? And do local subsidiaries of MNEs act as norm entrepreneurs or are they similarly constrained by the institutional base? We use data from an extensive international survey, with a more comprehensive and diverse range of HRM practices than in previous studies, to examine these under-researched temporal developments, offering a novel, non-dichotomous, approach to convergence/ divergence that better reflects the dynamic reality of international business. Consequently, we uncover new categories of the convergence/ divergence process and demonstrate these through our findings. We make an additional contribution by examining simultaneously convergence over time from two under-researched sub-dimensions of geographic location, i.e. market economy and location of operation (indigenous vs. foreign), as well as the interactions among these dimensions.

In the International HRM literature, there is a lively debate about the extent to which the actions of MNEs and a tendency towards global standardization are fueling convergence (Brewster, Mayrhofer, \& Smale, 2016; Edwards et al., 2016). This literature focusses on mezzo-level processes playing out in MNEs (Kaufman, 2016) arguing that HRM practices, like other management practices, are being standardized to a universal paradigm (Lawler, Chen, Wu, Bae \& Bai, 2011; Pudelko \& Harzing, 2008). While it is acknowledged that some MNEs are polycentric (Perlmutter, 1969) and make no attempt to standardize any of their practices, preferring to exploit subsidiary specific advantages (Rugman \& Verbecke, 2001), the predominant discourse suggests that many MNEs do attempt to standardize their operations globally. Other firms adopt the best practices of those that are more successful, believing that 
this will improve their own performance (Björkman, Smale, Sumelius, Suutari \& Lu, 2008). As practices are mimicked, with MNE subsidiaries providing examples to local businesses, convergence arises.

Perhaps, however, rather than converging, HRM is grounded in its institutional context and change is path dependent (Rosenzweig \& Nohria, 1994). Early research found that countries were becoming more different rather than converging in their macro-environmental characteristics, and that any similarity was more likely between proximal than distant countries (Craig, Douglas \& Grein, 1992). Comparative HRM literature asserts that firms are embedded in the country context in which they operate (Gooderham, Nordhaug \& Ringdal, 1999; Gunnigle, Murphy, Cleveland, Heraty, \& Morley, 2002), and as a result, are subject to local regulations and traditions affecting employment practices (Björkman, Fey \& Park, 2007; Huo, Huang \& Napier, 2002). This embeddedness literature, including comparative capitalisms (Hotho, 2014; Jackson \& Deeg, 2008), argues that we should not expect to see convergence and that, in practice, non-convergence is more likely to be the norm.

In short, the literature to date is equivocal as to whether convergence in HRM has been occurring globally. One reason is the current lack of integration across Comparative HRM and International HRM fields (Brewster et al., 2016; Kaufman, 2016). More specifically, the macro contexts of market economies have not been studied alongside the mezzo contexts of MNEs and their subsidiaries to see how these effects interact. We address this failing (Gooderham \& Nordhaug, 2011), building from Tempel and Walgenbach (2007), who critique both neo-institutional and comparative capitalisms theorizing for its lack of attention to firm-level analyses. Moreover, we address a shortcoming in extant convergence literature which largely relies on reporting consistent trends to identify convergence/ divergence (Kaufman, 2016). Given the non-consistent (dynamic) context in which firms are operating, we develop a more nuanced way of studying the convergence process that can incorporate the dynamics of firms' institutional contexts.

The empirical contribution of this study is its focus on data covering a broad range of HRM practices gathered over three points in time across multiple countries, based on the Cranet surveys. Prior studies using this database have focused on a narrower range of practices and/ or a shorter or more distant 
period of time - examples of these studies are summarized in Table 1. Other than Goergen, Brewster, Wood and Wilkinson (2012), who focus on organization-level analyses, all studies reported focus on country-level convergence. The most ambitious attempt was by Mayrhofer and colleagues (2011). With 2004-05 as their end-point, they examined three bundles of HRM practices (development, reward, communication) as well as the configuration of the HRM department. Their findings highlighted some common national trends (directional convergence) but little evidence of country-level practices being isomorphic. We expand on this and other studies by exploring a more recent time period (1999-2010), a broader range of HRM practices (17 individual practices), and including comparison of foreign MNE subsidiaries with indigenous organizations, in different market economies. As Mayrhofer et al. (2011: 63) note with regard to the need for future research: "the interplay between drivers at various analytical levels is crucial". This study is thus one of very few (see: D’Arcimoles, 1997; Guest, Michie, Conway, \& Sheehan, 2003) to explore change in the adoption of HRM practices over an extended period of time across multiple countries.

Insert Table 1 about here

\section{GLOBALIZATION, CONVERGENCE AND DIVERGENCE}

The international business (IB) literature has debated the globalization phenomenon in relation to HRM practice convergence (Edwards et al., 2016; Huo et al., 2002; Mayrhofer et al., 2011). Convergence is, by definition, a process that occurs over time, whereby organizations adopt more similar practices, leading ultimately to universal implementation ('final' convergence) or parallel trends ('directional' convergence) (Mayrhofer, Müller-Camen, Ledolter, Strunk, \& Erten, 2002; Mayrhofer et al., 2011). Divergence, in contrast, occurs when HRM practices being adopted by different organizations become more dissimilar over time. In most cases, extant research has focused on establishing whether convergence/ divergence is taking place or not, which leaves the field open to critique based on what Kaufmann (2016:339) 
describes as "the analytically problematic definition and measurement of the concept of HRM convergence-divergence". We present here arguments as to how a more nuanced conceptualization of the convergence/ divergence process (i.e. extent of convergence) might address some of the current theoretical shortcomings in the field.

The debate concerning the observed reality of convergence/ divergence is rife within the HRM literatures: The Comparative HRM literature largely argues for divergence due to the embeddedness of management practices within a given national context (Björkman et al., 2007; Gooderham et al., 1999; Gunnigle et al., 2002); while the International HRM literature observes the HRM activities of MNEs, presenting a stronger case for convergence based on standardization arguments of economies of scale and scope (Björkman et al., 2008; Edwards et al., 2016). This debate originated from the labor relations discipline, suggesting that work within industrial societies will look increasingly similar, because science and technology are universal (Kerr, Dunlop, Harbison, \& Meyers, 1960), and as technology spreads, there would be increasing convergence "over time and place" (ibid.: 10) towards a single model of industrial society. Later studies agreed (Colvin \& Darbishire, 2013; Katz, 1993), but noted that this extended further in some countries than in others (Marginson, Sisson \& Arrowsmith, 2003; Schnabel, Zagelmeyer, \& Kohaut, 2006).

We argue that the operationalization of 'geographic location' is creating the confusion as to whether convergence or divergence is dominating HRM: Adopting a country level of analysis, as Comparative HRM scholars most often do, largely leads us to a conclusion of divergence; adopting the MNE level of analysis tends to lead to conclusions of convergence or at least standardization. The critical factor that is not being discussed is that isomorphism occurs within a specific 'organizational field', defined as "a recognized area of institutional life: key suppliers, resource and product consumers, regulatory agencies, and other organizations that produce similar services or products" (DiMaggio \& Powell, 1983: 143). While firms react to isomorphic pressures in their particular field (e.g. country, industry, organization type, size of operation), nation states affect the extent of isomorphism across organizational fields (Scott \& Meyer, 1994; Tempel \& Walgenbach, 2007). To move this debate forward, 
we explore the HRM convergence/ divergence debate focusing on two levels of geographic location that have not been studied together before: market economy and the indigenous firm vs. MNE foreign subsidiary.

\section{Market economies}

Market economies are expected to differ in their pattern of HRM practice adoption and diffusion based on "systematically interdependent configurations" (Jackson \& Deeg, 2008: 545). The varieties of capitalism literature (Hall \& Soskice, 2001) identifies two ideal types of market economy - liberal market economies (LMEs) and coordinated market economies (CMEs). LMEs are the Anglo-Saxon societies (e.g. the U.S.A., U.K., Australia), dominated by shareholder ownership, focused on short-term profit maximization, preferring a minimal role for government, with deregulated labor markets and strong market competition. CMEs, typified by Germany, have a wider stakeholder approach, higher regulation of the labor market and hence less firm autonomy, with a longer-term focus on return on investment. In LMEs, internal relationships echo the competitive and utilitarian relationships of the external market, while in CMEs there is more employer-employee interdependence (Hall \& Soskice, 2001).

The comparative capitalisms literature argues for 'institutional complementarities', whereby the characteristics of each type of market economy give them their value (Höpner, 2005), and institutions work together to reinforce or substitute for each other in a way that creates economic success, creating within market economy convergence and between market economy divergence. This is in line with institutional logics theory, which identifies the "socially constructed historical patterns of cultural symbols and material practices, including assumptions, values and beliefs, by which individuals and organizations provide meaning to their daily activity, organize time and space, and reproduce their lives and experiences" (Thornton et al., 2012: 2). These logics align at the level of organizational fields, producing institutional complementarities (Hall \& Soskice, 2001) that represent mutually reinforcing relationships between different institutional logics at societal or organizational levels. 
The comparative capitalisms literature struggles, however, to deal with two issues related to convergence. One is change over time (Thelen, 2014). The liberalization thesis posits that the AngloSaxon model of LMEs is increasingly penetrating CMEs, leading to convergence to the LME model (Schneider \& Paunescu, 2012). Alternatively, it has been argued that, despite this liberalization trend, substantial differences remain between market economies (Hall \& Thelen, 2009). Thelen (2014) suggests that although there may be a growing movement in favor of certain kinds of institutional liberalization in CMEs, these may not lead to firms there operating more like LMEs. Such debates are typical of what is described as institutional change (Dacin, Goodstein, \& Scott, 2002): Institutions are formed over time, but the actors who are operating within these institutional constraints can also effect change, in turn creating new institutional conditions. The implication here is that a more nuanced understanding of the convergence/ divergence process may be required.

\section{Indigenous firms vs. foreign MNE subsidiaries}

A second issue that the comparative capitalisms literature struggles with is the role of MNEs (indeed, they are not mentioned in Hall and Soskice, 2001). If we take the case of MNE subsidiaries operating in a host country, these operations require an alternative conceptualization of the 'organizational field' as they operate beyond national or market economy boundaries (Kostova, Roth, \& Dacin, 2008; Tempel \& Walgenbach, 2007), and are thus faced by multiple, potentially conflicting, institutional contexts. MNEs may attempt to leverage advantages from their global presence, hence foreign subsidiaries are not independent of the parent (Poutsma, Ligthart, \& Veersma, 2006). MNE headquarters may try to impose standardized policies to subsidiaries in host countries, believing that their way of operating is what has created the firm's particular advantage and that it is likely to hold in all contexts (Dore, 2008). MNE subsidiaries are, however, neither independent of headquarters, nor independent of the country in which they are located, where local institutions can play both constraining and enabling roles (Andersson, Forsgren, \& Holm, 2001; Saka-Helmhout, Deeg, \& Greenwood, 2016). 
In any country, innovation may come from outsiders, such as MNE subsidiaries, who have fewer ties and less commitment to an existing order (Dore, 2008). Indigenous firms might in turn be influenced by foreign MNE subsidiaries and move their practices closer toward them. Evidence points towards noticeable convergence effects of these global players on HRM practices in host countries (Almond, Edwards, \& Clark, 2003; Farndale, Brewster, \& Poutsma, 2008; Ferner \& Quintanilla, 1998; Gooderham et al., 1999; Poutsma, Ligthart, \& Schouteten, 2005). Nevertheless, although local managers in the host country may embrace or resist the standardization of practices (Edwards, Sanchez-Magnas, Tregaskis, Levesque, McDonnell, \& Quintanilla, 2013), they are unlikely to have total autonomy in their foreign operations (Kostova \& Roth, 2002). Any evidence of convergence/ divergence is likely, therefore, to be complex and may not be linear in its progression.

\section{INSTITUTIONAL CONTEXT OF HRM PRACTICES}

HRM has long been a particular concern in the IB literature - being one of the most costly yet important resources for all organizations, and being particularly complex to manage when operating across national borders. Macro-level differences in practices, usually between countries (Brewster \& Mayrhofer, 2012; Kaufman, 2016), are often explained through neo-institutional, comparative capitalisms theorizing (Festing, 2012; Goergen et al., 2012). Institutions ("the rules of the game": Kaufman, 2007: 14) are argued to constrain the discretion of organizational actors to adopt certain practices, but the durability and determinism of institutional differences has been questioned (Saka-Helmhout et al., 2016).

Institutional constraints can be broadly defined as comprising elements of legitimacy and efficiency (Kostova \& Zaheer, 1999). Legitimacy is achieved when HRM practices are aligned with internal and external expectations, including legislative requirements and employee/ employer interests, whereas efficiency is focused on achieving optimal use of resources. All areas of HRM are subject to some form of institutional constraint, but some practices are expected to have a higher threshold to achieve legitimacy (i.e., those subject to strong traditions or regulations), while others can display greater 
variation in practice with all forms similarly being considered legitimate so that efficiency may be more deterministic of organizational practice.

Our theorizing around the extent to which we expect to observe convergence/ divergence related to higher or lower levels of institutional constraint is based on the two core arguments presented by the varieties of capitalism and IB literatures. The former relies on arguments that there will be greater similarity within a market economy than between market economies due to the differential extent of regulation of firms' HRM activities across market economies (Hall \& Soskice, 2001; Jackson \& Deeg, 2008). The IB argument acknowledges the prevalent institutional constraints, but argues that indigenous firms are more embedded in the local context and thus will show more extensive use of constrained practices (Looise \& Drucker, 2002) compared to foreign MNE subsidiaries. Although the subsidiaries must comply with certain constraints, they are not independent of the (foreign) parent (Poutsma et al., 2006), and have local managers who are influenced by headquarters' pressures for implementation of a standard global strategy (Edwards et al., 2016; Kostova \& Roth, 2002).

In summary, we predict considerable variation in HRM practice use between LME and CMEbased firms due to the different sets of institutional constraints, so that convergence of such practices is not expected to occur between CME and LME contexts. Similarly, we predict considerable variation in HRM practices between indigenous firms and foreign MNE subsidiaries, as well as less convergence due to continued standardization pressures faced by subsidiaries from the parent headquarters. We apply this reasoning to five areas of HRM practice (compensation, wage bargaining level, contingent employment, direct employee information provision, and training), illustrating why we anticipate each area might be considered more or less institutionally constrained. This in turn allows us to hypothesize which HRM practices are expected to vary or converge over time.

Compensation practices are impacted by considerable differences in national pay structures, and fiscal policies (Fay, 2008; Festing, Engle, Dowling, \& Sahakiants, 2012), and are frequently regulated at the national level in terms of statutory pay or minimum benefits. Financial participation schemes, as part of compensation packages, are also subject to local legislation, tax concessions, and industrial relations 
systems and ideologies (Pendleton \& Poutsma, 2012). Institutional constraints are high for compensation practices, as they are path dependent, tied into local norms, traditions, and corporate governance mechanisms (Festing \& Sahakiants, 2010). We therefore predict considerable variation (and a lack of convergence) in compensation practices between LME and CME firms, as well as between indigenous firms and foreign MNE subsidiaries.

We posit that the level at which wage bargaining occurs is similarly context-dependent, commonly influenced either through voluntarist systems or national legal frameworks (Brewster, Wood, \& Brookes, 2008). Discretion regarding what is considered legitimate is potentially less where regulation is substantial (in CMEs: Thelen, 2001), such as a requirement to deal with employee representatives (Björkman et al., 2007; Huo et al., 2002). Similarly, less discretion is expected where MNE parents impose standardized policies, although the extent to which local managers in the host country embrace or resist these practices varies (Edwards et al., 2013; Kostova \& Roth, 2002). An interaction effect of market economy and MNE strategy has also been found related to wage bargaining, with evidence that HRM practice is localized in more regulated European countries, particularly among European- rather than U.S.-owned MNEs (Gunnigle et al., 2002).

Contingent employment contracts have legitimacy constraints driven by legislation in many countries. For example, in Europe, numerous reforms have promoted contingent employment by ensuring that it is regulated (Gialis \& Taylor, 2016; Williams \& Padmore, 2013). Firms choose to use their workforce flexibly, contingent on fluctuations in demand, changes in the organization of production, and the periodic crises typical of the capitalist mode of production (Kalleberg, 2003). Nevertheless, Tregaskis and Brewster (2006: 122), studying contingent employment contracts in Europe, conclude: "There is no evidence that either the regional institutional pressures coming from the European Commission or regional or global competitive pressures are creating 'final' convergence in organizational practice”. In other words, there are elements of legitimacy requirements in terms of meeting legislative requirements, but within those constraints contingent employment may largely be driven by more efficiency-related firm-level criteria. This leads us to predict that contingent employment practice will show less variation 
between, and therefore be more likely to converge across, market economies, and when comparing indigenous firms and foreign MNE subsidiaries.

We posit that training may also be weakly institutionally constrained, despite having countryspecific elements including local skill requirements, different skill formation trajectories (Thelen, 2004), and a range of government investment levels in education (Tregaskis \& Heraty, 2012). Organizations likely consider these factors when devising training strategies, but are not compelled to implement particular practices. Efficiency may therefore be considered a stronger driver than legitimacy. There is evidence, for example, from comparative OECD studies (1995-2002) that training is largely dependent on R\&D investments and deregulation of sectoral product markets, and less on, for example, unionization (Bassanini \& Brunello, 2011). Training tends to vary with economic cycles, with budgets quickly being cut in a downturn (Goergen et al., 2012), being a matter of organizational choice rather than an institutional demand. We therefore predict that training demonstrates considerable leeway for organizations to choose which practices to adopt, largely avoiding institutional constraint.

The direct provision of information to individual employees is perhaps one of the areas of practice least institutionally constrained (Brewster, Wood, \& Goergen, 2015). For example, although European Union regulations set minimum standards around employee communication, these are largely concerned with collective and representative forms of communication rather than individual communication (Kessler, Undy \& Heron, 2004). Direct employee information provision is therefore largely left to management discretion. From a legitimacy perspective, greater provision may be driven by the general climate of information sharing (i.e. what is normal practice), whereas an efficiency perspective might observe that managers feel constrained to provide information only when it is perceived that a positive outcome will occur.

There is an additional layer of complexity when considering the interaction effect on convergence between market economies and foreign MNE operations. Extant research provides evidence of such an effect. HRM practices vary between foreign-owned MNEs, domestic-owned MNEs and domesticallyoperating organizations, and these variations have been found to be smaller in CME than LME contexts 
(Farndale et al., 2008). Similarly, Gooderham et al. (1999) found that U.S. MNE subsidiaries largely maintained their practices in other LMEs but they made more adjustments in their subsidiaries in CMEs, while Gunnigle et al. (2002: 276) noted "nationally embedded barriers to diffusion in strong regulatory environments". This evidence implies that the local norms in LMEs may be closer to those of the foreign MNEs or that they allow MNEs more discretion than do norms in the more tightly regulated CMEs (Fenton-O’Creevy, Gooderham, \& Nordhaug, 2008).

In summary, we have argued that the extent of variety and convergence will be affected by a broad set of institutional constraints, i.e. a combination of legitimacy and efficiency drivers of organizational practice, determined at least in part by the market economy in which the firm is operating and whether it is operating as an indigenous firm or a foreign MNE subsidiary. In order to develop a more comprehensive definition of 'the extent of convergence', the empirical study that follows attempts to categorize convergence, from which future research might benefit. In order to achieve this, we test two hypotheses based on the theorizing presented:

H1: There will be greater variation in the use of compensation and wage bargaining level practices than in the use of contingent employment, training, and direct information provision practices, when comparing between: (a) liberal and coordinated market economies; (b) foreign MNE subsidiaries and indigenous firms; and (c) foreign MNE subsidiaries and indigenous firms embedded in liberal and coordinated market economies.

H2: Convergence will be more likely in the use of contingent employment, training, and direct information provision practices than in the use of compensation and wage bargaining level practices, when comparing between: (a) liberal and coordinated market economies; (b) foreign MNE subsidiaries and indigenous firms; (c) and foreign MNE subsidiaries and indigenous firms embedded in liberal and coordinated market economies.

\section{METHODOLOGY}


In order to test the hypotheses, we use data from the on-going Cranet surveys on HRM. The Cranet questionnaire is designed by an international team in English, translated and back-translated (Brislin, 1976) into the language(s) of each country, and minimally revised between rounds of data collection to maintain consistency over time. The survey is distributed either by paper, telephone, or online (depending on location) by partners based in each of the participating countries, with each collecting its own sample data, later combined into an international dataset. The survey is targeted at senior-level managers responsible for HRM, who are selected as key informants as they are likely to be well-versed in the firm's HRM practices (Huselid \& Becker, 2000).

Response rates for the individual countries represented here vary between $8 \%$ and $37 \%$, with a mean of $18 \%$. HR managers are asked to respond on items that cover many of the HRM practices in their organization, predominantly asking for yes/ no answers or for numbers or percentages. Example questions are: 'Approximately what proportion of the annual salaries and wages bill is currently spent on training?' (open response); 'Please indicate the approximate proportion of your workforce who are on each of the following working arrangements: part-time, temporary, fixed-term contracts' (answer options: not used/ $<1 \% ; 1-5 \% ; 6-10 \% ; 11-20 \% ;>20 \%)$.

We use evidence from nine countries and three rounds of the survey carried out in 1999-2000 (time 1), 2004-05 (time 2), and 2009-10 (time 3). We exclude organizations that: (a) are public or semi-public, and (b) employ less than 100 employees. Both groups tend to have a distinctive nature with regard to HRM, which makes cross-national comparisons more complex to interpret when simultaneously including larger organizations and the private sector (Bozeman \& Loveless, 1987). In total, 5,743 cases across the three time intervals of data collection are included (see Table 2). $96.3 \%$ of respondents were (senior) HRM practitioners. Across the whole sample, the median respondent organization size is 445 employees. The sampling frames used in each country generally produce stratified representative samples, and are consistent with those generated by other studies. The partners of the network report the representativeness of the country sample according to industry, size, and private-public sector proportions. The sample of the 
countries included in this study is largely representative except for the private-public divide, which is not relevant here.

Insert Table 2 about here

\section{Measures}

Organization type. Organizations are defined as a 'foreign MNE subsidiary' when the respondent identifies the home country of the firm's headquarters as being other than the country in which the firm is operating. Otherwise the organization is defined as 'indigenous'.

Market economy. The country from which the data were collected defines the market economy. Based on Hall and Soskice (2001: 19-20), the UK and Australia are examples of LMEs, while Austria, Belgium, Denmark, Finland, Germany, the Netherlands and Sweden are examples of CMEs. The imbalance in the number of LME (two) and CME (seven) countries may be a limitation to the study, though it reflects the smaller number of LMEs in the world and is the same for many previous studies using comparative capitalisms theories. Australia was also the only non-EU country in the sample, although as an LME country it fits the comparative capitalisms analysis. Additional analyses were conducted comparing the default model with a model including Australia as an additional main effect. The results for the two models (available from the authors) were substantially similar, providing confidence that the model estimations are stable, and that there is no noticeable EU effect on the data.

HRM practices. Compensation, wage bargaining level, contingent employment, information provision, and training practices were selected as a broad range of HRM practices. Respondents reported the extent of adoption of a range of individual practices in each of these areas. Table 3 provides an overview of the HRM practice variables and the percentage of organizations indicating use of the practice. 
Control variables. Firm characteristics (industry, organization size, trade union membership rate) are included as control variables given their pertinence to the 'organizational field' (Gooderham et al., 1999; Rosenzweig \& Singh, 1991).

Table 4 presents the correlations across the whole dataset. There were no issues of multicollinearity among the independent variables, with variance inflation factors (VIF) of main effects ranging from 1.05 to 2.68 . We conducted a multi-level random-intercept regression model using STATA (v14.2), using STATA’s (v13.1) program GLLAMM (v2.3.20) (Rabe-Hesketh \& Skrondal, 2004, 2005) as the dataset includes organization-level data of 5,743 firms nested in the nine countries ${ }^{1}$. The intracountry coefficients across the HRM variables range significantly between 0.02 and 0.19 (on average 0.09), supporting adopting the multilevel analysis approach. For all HRM practices, the full model results are significantly different from the random intercept only model with $\mathrm{R}^{2}$ ranging from .04 to .27 (mean $=$ $0.10)$.

Insert Table 4 about here

\section{RESULTS}

The following results present the hypothesized effects, above and beyond the impact of country, year and firm-level firm characteristics ${ }^{2}$. After examining the findings, the pattern of effects is categorized according to the extent of convergence observed, ranging from 'constant no difference' via 'robust convergence' and 'robust divergence' to 'constant difference' (see Table 5). To explain this further, we first present the effects of market economy (LME vs CME) and its impact on convergence (Table 6), 
followed by the effects of organization type (foreign MNE subsidiary vs indigenous firm) (Table 7). Finally, we explore whether the interaction effects of market economy and organization type suggest convergence within the timeframe studied (Table 8).

Insert Table 5 about here

Observing the hypothesized (H1a) baseline LME simple effect (the effect in 2009-10 at the end of our timeframe ${ }^{3}$ ), there are four practices with significant odds ratios (Table 6). Based on the size of the odds ratio, reported here in decreasing order, company wage bargaining $(4.49, \mathrm{p}<.01)$, employee share ownership $(2.70, \mathrm{p}<.01)$ and group bonus $(1.96, \mathrm{p}<.01)$ are used significantly more in LMEs than in CMEs, while individual level bargaining $(0.37, \mathrm{p}<.05)$ is used significantly less. This provides some support for H1a as half of the compensation and wage bargaining level practices show significant differences in the likelihood of use across market economies, whereas there are no contingent employment, direct information provision, or training practices with significant differences.

Insert Table 6 about here

To test for the occurrence of convergence in the use of each practice $(\mathrm{H} 2 \mathrm{a})$, we first observe the LME effect, exploring the odds ratios comparing time 1 to time 3 and time 2 to time 3 (Table 6 interaction effects). All of the contingent employment (except for temporary contracts), direct information provision, and training practices indicate no significant difference in odds ratios for any of the time points studied. We refer to these cases as having 'constant no difference', i.e. the practice may have converged at some point in the past or never been different between market economies. Temporary contracts showed a pattern of robust convergence.

In contrast, the wage level bargaining and compensation practices show more variation. There are three practices for which there is a significant odds ratio at time 3 (company level bargaining, employee 
share ownership, group bonus) and that show a pattern of 'non-robust divergence', i.e. practices show an irregular trend of difference over time ending in significant difference in 2009-10. Two practices show a pattern of 'robust convergence' (site level bargaining, profit sharing): The significant odds ratio comparing time 1 to time 3 decreases in size when comparing time 2 to time 3 , and is non-significant in the baseline. There are also two practices that do not have significant odds ratios in the baseline (national level bargaining, performance related pay) that show an irregular trend of convergence over the time period studied, i.e. the odds ratio is non-significant when comparing time 1 to time 3 but significant when comparing time 2 to time 3. We label this 'non-robust convergence'. Finally, individual level bargaining shows 'constant difference': The odds ratio is significant in the baseline, but non-significant at the two comparison time points.

Overall, this gives some support for $\mathrm{H} 2 \mathrm{a}$ as all contingent employment, training, and direct information provision practices displayed some form of convergence, while this was only true for half of the compensation and wage bargaining practices.

Testing H1b (Table 7), foreign MNE subsidiaries differ significantly from indigenous firms for nine practices, six of which are wage bargaining and compensation practices. Foreign MNE subsidiaries make significantly more use (in decreasing order of size of the odds ratios) of employee share ownership $(2.79, \mathrm{p}<.01)$, group bonuses $(2.16, \mathrm{p}<.01)$, performance-related pay $(2.14, \mathrm{p}<.01)$, workforce briefing on finance $(1.51, \mathrm{p}<.05)$, company level bargaining $(1.50, \mathrm{p}<.05)$, strategy briefing $(1.40, \mathrm{p}<.05)$ and site level bargaining (1.30, $\mathrm{p}<.05)$. They also make significantly less use of national level bargaining $(0.68$, $\mathrm{p}<.01)$ and part-time contracts $(0.57, \mathrm{p}<.01)$. Overall there is support for H1b as three quarters of the wage bargaining and compensation practices demonstrate variation, whereas this is only true for one third of the contingent employment, training, and direct information provision practices.

Insert Table 7 about here 
$\mathrm{H} 2 \mathrm{~b}$ explores convergence of practices over time between MNE subsidiaries and indigenous firms. Five of the nine contingent employment, indirect information provision and training practices show a pattern of 'constant no difference', while two demonstrate 'robust convergence'. In line with H2b expectations, only two practices do not demonstrate convergence: Strategy briefing shows 'non-robust divergence' and part-time contracts 'constant difference'. In contrast, six wage bargaining level/ compensation practices demonstrate some degree of divergence, with only two practices (individual level bargaining, profit sharing) showing a pattern of 'constant no difference', again largely in line with H2b.

Observing the hypothesized (H1c) interaction effect between LME and foreign MNE subsidiaries in 2009-10 (Table 8), there are five practices with significant odds ratios. Decreasing in odds ratio size, these are temporary contracts $(2.27, \mathrm{p}<.05)$, strategy briefing $(1.52, \mathrm{p}<.05)$, site level bargaining $(0.74$, $\mathrm{p}<.01)$, part-time contracts $(0.57, \mathrm{p}<.01)$, and employee share ownership $(0.45, \mathrm{p}<.01)$. Testing these interactions, H1c is not supported as only one quarter of the compensation and wage bargaining level practices show significant differences in the likelihood of use, whereas one third of the contingent employment, training, and direct information provision practices show significant differences.

Insert Table 8 about here

When we examine convergence and the combined effects of market economy and foreign MNE subsidiary versus indigenous firms (H2c) (Table 8), 11 of the 17 practices observed show a trend of 'constant no difference'. The exceptions are: a pattern of 'non-robust divergence' for share ownership, strategy briefing, part-time and temporary contracts; 'constant difference' for site level bargaining; and 'non-robust convergence' for national level bargaining. These findings do not support $\mathrm{H} 2 \mathrm{c}$ as the spread of convergence and divergence trends observed does not align with the expected division by practice areas.

Looking across the findings, Figure 1 demonstrates the simultaneous relevance of market economy and foreign MNE subsidiary vs indigenous firms, relative to other factors included in the study. 
As can be observed, country remains a dominant factor in many practice areas, however, market economy and foreign MNE subsidiary are, in addition to year and firm characteristics, important variables in understanding HRM practice adoption.

Insert Figure 1 about here

\section{DISCUSSION}

This study has applied institutional theorizing to improve our understanding of convergence/ divergence as an outcome and as a process. The notion of institutionally-constrained HRM practices was introduced to explore the extent to which complementarities and isomorphism occur within a specific 'organizational field' (DiMaggio \& Powell, 1983), exploring both market economy and foreign MNE subsidiary vs indigenous firm effects. While prior convergence research has primarily been restricted to observing the country or market economy organizational fields, we have extended this literature by including the dual (simultaneously global and local) organizational fields applicable to foreign MNE subsidiaries (Kostova et al., 2008; Tempel \& Walgenbach, 2007).

Our findings that convergence/ divergence occurs to different extents (i.e. is graded) provides empirical support for Kaufman (2016), who highlights the problems of current definitions of convergence, explaining the lack of inclusion of alternative permutations such as different conclusions being drawn depending on the time point at which comparisons are made. We argue that the convergence question is both contextual and temporal and is not a simple linear phenomenon given the dynamic contexts in which firms operate. We have therefore proposed a more graded conceptualization of convergence/ divergence ranging from constant no difference, through robust convergence, non-robust convergence, non-robust divergence, and robust divergence to constant difference. This allows us to tease out the more subtle manifestations of the process that can incorporate institutional context dynamics. 
In order to provide this more graded conceptualization, we examined a diverse range of individual HRM practices, each one illustrative of practices that may be more or less affected by institutional constraints. The logic of market economy isomorphism would be that the practices most deeply embedded in the local context would be the least likely to converge across market economies (Hall \& Soskice, 2001; Hotho, 2014). Similarly, we argued that the most institutionally-embedded HRM practices would be least likely to converge across indigenous firms vs foreign MNE subsidiaries: Whereas indigenous firms are strongly embedded in their local context, foreign subsidiaries are independent of neither the parent company nor the host setting (Looise \& Drucker, 2002; Poutsma et al., 2006) and hence will be less likely simply to align with local firms. Specifically, we expected (and largely found) that the degree of institutional embeddedness would decrease (and the degree of convergence increase) when comparing the use of compensation and wage bargaining level practices with the use of contingent employment, training, and direct information provision practices.

We first hypothesized that we would observe differences in the extent of HRM convergence based on the degree to which a practice area might be constrained by market economy institutional complementarities (Höpner, 2005). This was supported for half of the wage bargaining level and compensation practices studied (company and individual level bargaining, employee share ownership, and group bonus) aligned with predictions from comparative capitalisms theories (Hall \& Soskice, 2001; Jackson \& Deeg, 2008). For such institutionally-constrained practices, we also expected market economy differences to endure over time (Hall \& Thelen, 2009). This was supported for the same four practices. We therefore surmise that these practices are particularly strongly institutionally constrained, rooted in fundamental differences in the employment relationship between the LME and CME contexts.

In contrast, contingent employment (except temporary contracts), training, and direct information provision practices all demonstrated constant no difference between market economies, indicating that either practice has converged at some point in the past, or any differences are due to factors other than market economy. We conclude that these practices are less constrained by market economy institutions, and hence firms have greater leeway over choosing which practices to adopt (Hall \& Soskice, 2001; 
Hotho, 2014). Any institutional context is therefore not in itself determinative of the practices adopted by firms: Powerful firms have some leeway over how they adapt to institutional constraints for some HRM practices (Crouch, 2005; Jackson \& Deeg, 2008), driven at least in part by the direction of the firm's corporate strategy and the actions of management.

We also observed nine practices showing significant difference in their likelihood of use between foreign MNE subsidiaries and indigenous firms. Six of these nine practices were wage bargaining and compensation practices, each indicating some degree of divergence. This again supports our argument that such practices are more institutionally constrained (Festing \& Sahakiants, 2010; Thelen, 2001). In practice, indigenous firms likely adopt the norms of their country, with foreign firms showing less mimetic isomorphism (Pudelko \& Harzing, 2007; Saka-Helmhout et al., 2016). For less institutionally constrained practices, however, there is again more commonality of practice across firm operating locations. This is in line with Edwards et al. (2016), who explored the standardization of performance management (arguably also less institutionally-constrained), comparing practice adoption between indigenous and U.S.-owned MNEs across six European countries. They argued that countries with stronger institutional constraints reduce the adoption of typical U.S. performance management practices, though they conclude that such evidence is still limited.

Although our findings are broadly supported by the existing literature as we have noted, there are several areas of unexpected details in the results. For example, we found that individual bargaining is used less in LMEs compared with indigenous firms in CMEs (although the odds ratio is small). This may be explained by the ongoing trend of decentralization and hybridization of collective bargaining in the CME context. National level bargaining in CMEs has come under pressure and is increasingly combined with bargaining at lower levels in order to leverage more flexibility in terms and conditions of employment (Traxler, Arrowsmith, Nergaard, \& Molins Lopez-Rodo, 2008; Kalmi, Pendleton, \& Poutsma, 2012). There is also a significant positive association between national and individual level bargaining in CMEs suggesting more leeway in setting labor terms and conditions individually. The strong significant negative association between company and individual level bargaining in LMEs 
suggests more single level bargaining in LMEs compared to multilevel bargaining in CMEs: There is a trade-off between increased company, site and individual level bargaining in LMEs. We were also surprised that, compared to indigenous firms in CMEs, foreign MNE subsidiaries in LMEs tend to have lower use of part-time work. That may be because in CMEs part-time jobs are preferred to temporary and fixed-term contingent work arrangements due to its more stable character and greater employeecenteredness: In LMEs the more employer-centered flexibility and efficiency offered by temporary and flexible working are more accepted (Chung \& Tijdens, 2013; Williams \& Padmore, 2013). Finally, the greater use of strategy briefings in foreign MNE subsidiaries in LMEs compared to indigenous firms in CMEs may initially seem to be a surprise, but can be explained as the mirror image of the lower use of trade union and works council channels for communication.

Observing both market economy and organization type over time ( $\mathrm{H} 1 \mathrm{c}$ and $\mathrm{H} 2 \mathrm{c}$ ), we noted very few three-way interaction effects, indicating that the direct effect of these two factors over time has greater explanatory value. The findings indicate that HRM practice adoption in foreign MNE subsidiaries in LMEs rarely varies significantly from indigenous firms in CMEs. This could in part be related to characteristics of our sample: Only one third of the sample represented foreign MNE subsidiaries reporting strong control of HRM from headquarters, whereas two thirds reported being able to adapt HRM practices to the local context. This speaks to extant understanding that MNEs prefer to exploit subsidiary specific advantages (Rugman \& Verbecke, 2001). In addition, in identifying ‘foreign' MNE subsidiaries, the parent headquarters could be operating in the same type of market economy as the subsidiary, potentially diluting any 'foreign' effect. Future research might tease out these complex relationships in greater detail.

Our findings indicate that whether we observe HRM practice adoption through the lens of market economies or of indigenous firms vs foreign MNE subsidiaries, we find a similar pattern of compensation and wage bargaining level practices being more embedded (and less likely to converge across market economies or firm operating locations) than contingent employment, training, and direct information provision practices. These findings demonstrate the need for more detailed theories of MNE global 
standardization and of comparative capitalisms. Both sets of theories have tended to focus on economic pressures and institutional differences independently and have, perhaps inevitably, looked for measurable areas of institutional difference and similarity. There may, however, be important effects of 'soft' institutions (North, 1990). It may be, for example, that executives in MNEs choose to localize rather than standardize practices (counter to corporate strategy), because of the costs of overturning local assumptions about legitimate behavior. In this respect, the focus on hard institutional differences in these theories may need to be modified.

The findings also raise theoretical challenges for the role of MNEs as understood in the IB literature. Comparing to indigenous firms, foreign MNE subsidiaries in any particular locale show both differences and similarities in their use of HRM practices. This provides some support for the validity of MNE organizational fields needing to balance global and local factors, supporting the ideas of duality (Kostova et al., 2008) and of the hybridization of HRM practices (Chung, Sparrow, \& Bozkurt, 2013). Overall, our findings indicate that there are HRM practice areas where a more graded concept of convergence/ divergence helps us understand the processes that play out in dynamic firm contexts. As Figure 1 demonstrates, future research requires careful and detailed analysis to understand the range of antecedents affecting the patterns of use of HRM practices in firms internationally.

\section{CONCLUSIONS}

The simultaneous study of market economies and foreign MNE subsidiaries vs indigenous firms presented here brings together what have previously been two parallel streams of discussion around convergence and standardization in the Comparative and International HRM literatures. This has allowed us to develop a more graded understanding of convergence/ divergence than has been available to date. We have also been able to apply our theorizing to a more comprehensive and diverse range of HRM practices than has been done hitherto.

Despite the intriguing findings, our study, of course, has certain limitations. Firstly, the survey uses a single respondent approach, although the critical issue is the collection of data from the most 
knowledgeable sources. Obtaining more raters may increase reliability but, except in cases where the views of the respondents or areas of their specific knowledge are being studied, will not increase the accuracy (validity) of the raters' evaluations. In short, it is not simply how many people respond to a survey that is critical but whether the respondents are knowledgeable (Huselid \& Becker, 2000).

The study is also limited by the use of 'country' as a proxy control variable rather than including other national economic indicators that might capture change over time. It was decided not to include economic indicators given the broadly similar level of economic development of the countries included and a lack of variance in GDP growth over the timespan studied (all, broadly speaking, being rich countries with similarly qualified workforces). Although interesting for future studies, we also did not develop hypotheses at the industry or organization size level for similar reasons. These will be important variables to consider in future research as they are known to influence HRM (Gooderham et al., 1999; Rosenzweig \& Singh, 1991).

The response rate within each country might also be considered a limitation. The rates are comparable with other large scale, international surveys (Mayrhofer et al., 2011) and are acceptable for whole-population samples, as the survey is in many smaller countries. Obviously more respondents are always preferred, but since our interest is in comparative trends, the sample within each country is broadly representative of the economies, as measured against Eurostat and NACE evidence, rather than being matched in terms of sector and size or the proportion of MNEs. Cranet data, although longitudinal, are not the result of a panel survey. It is a repeated cross-sectional design in which longitudinal data is collected "on the same set of variables for (and perhaps at) two or more periods to include non-identical but comparable cases in each period" (Menard, 2007: 2-3). This repeated cross-sectional form of noncohort longitudinal analysis is "well-suited to examine change in values of variables in relationships" (ibid: 6).

The analysis is also limited to some extent by our selection of HRM practices, although we argue that they are illustrative of practices that may be either more or less institutionally constrained. We urge future research to continue to focus on individual HRM practices (rather than HRM system bundles), as 
our findings indicate clear variability in practice adoption in our comparisons. We were also limited to nine countries, and the results therefore may not be generalizable to other LME and CME contexts. Future research could focus on other interesting examples of LME countries (e.g. U.S.A.) and CME countries (e.g. Japan). The LME/ CME dichotomy that we used is the most frequently adopted in empirical research into comparative capitalisms, but more nuanced market economy taxonomies (Amable, 2003; Hotho, 2014) could have been adopted.

Finally, future research might explore why certain trends might be occurring over specified time periods. We limited ourselves to discussing convergence in terms of the equal likelihood of use of a practice, avoiding conclusions about directionality. Future research might involve qualitative studies that explore changes in HRM practice to uncover the dynamic processes behind convergence trends. For example, moving forward from our 2009-10 end point, it will be interesting to see the impact that the global financial crisis that began in 2008 had on HRM practice adoption over the longer-term.

Despite these limitations, the findings presented here can assist HRM leaders to understand the influences on their field of expertise, recognizing the importance of the context in which they are embedded at the firm and market economy level. Foreign MNE subsidiaries have different practices in place compared to indigenous firms but need to fit in locally, at least to some extent, i.e. the best form of economic organizing is that which delivers both efficiency and legitimacy (Kostova \& Zaheer, 1999). When considering whether to adopt a strategy of globalization or localization, or some hybrid approach, MNEs can assess the potential challenges they may face by considering the extent to which the institutional constraints around specific HRM practices might vary across the parent and host locations. By undertaking such an analysis, implementation of the strategy might be both more efficient and yield higher returns.

We suggested criteria against which firms might determine the extent to which different HRM practices are more or less institutionally-constrained. The evidence presented here points to wage bargaining levels and compensation practices offering less leeway for local adaptation away from institutional norms, compared with contingent employment, direct information provision and training 
practices. The constraining element of institutions therefore needs to be considered per area of practice to avoid over- or under-statement. Overall, this study has highlighted that institutions matter: For firms, this means that discretion is limited unless they are able to influence these institutions. To this end, in some countries, particularly the CMEs where competition is less of a requirement, firms organize themselves into business/ employer associations to be part of the institutional context and to instigate favorable arrangements.

In conclusion, our study provides insights into the phenomenon of HRM practice convergence/ divergence, offering a multi-faceted reflection of reality. This poses a challenge to theories of 'constant white water change', as much as it does to theories such as those dealing with comparative capitalisms that struggle to explain change. By adopting a more graded concept of convergence/ divergence and applying it simultaneously to market economy and foreign MNE subsidiaries vs indigenous firms, our study has revealed a more complex but arguably a more realistic picture than previous attempts to study convergence in HRM. Our assumptions of institutional constraint (or a lack thereof) were largely supported, offering a way forward in the understanding of which HRM practices are more likely to converge over time and which are more likely to remain distinctive.

\section{ENDNOTES}

${ }^{1}$ OLS regression would have resulted in unreliable standard deviations because the assumption of independent observations would have been violated (Snijders \& Bosker, 1999).

${ }^{2}$ Full models are available on request from the authors.

${ }^{3}$ Given the higher-order interaction parameters in the model, the lower-order parameters (e.g. LME) test conditional effects providing the baseline odds ratios for the reference group. In our model, the reference group contains organizations in the last year of our timeframe (2009-10). The corresponding interaction parameters involving the preceding years test whether firms in specific years have an additional effect beyond the baseline effect (see: Ai \& Norton, 2003). 


\section{REFERENCES}

Ai, C. R., \& Norton, E. C. 2003. Interaction terms in logit and probit models. Economics Letters, 80(1): 123-129.

Almond, P., Edwards, T., \& Clark, I. 2003. Multinationals and Changing National Business Systems in Europe: Towards the 'Shareholder Value' Model? Industrial Relations Journal, 34(5): 430-45.

Amable, B. 2003. The diversity of modern capitalism. Oxford, UK: Oxford University Press.

Andersson, U., Forsgren, M., \& Holm, U. (2001). Subsidiary embeddedness and competence development in multinationals: a multi-level analysis. Organization Studies, 22(6), 1013-1034

Bassanini, A., \& Brunello, G. 2011. Barriers to entry, deregulation and workplace training: A theoretical model with evidence from Europe. European Economic Review, 55(8): 1152-1176.

Björkman, I., Fey, C. F., \& Park, H. J. 2007. Institutional theory and MNC subsidiary HRM practices: Evidence from a three-country study. Journal of International Business Studies, 38(3): 430-446.

Björkman, I., Smale, A., Sumelius, J., Suutari, V., \& Lu, Y. 2008. Changes in institutional context and MNC operations in China: Subsidiary HRM practices in 1996 versus 2006. International Business Review, 17(2): 146-158.

Bozeman, B., \& Loveless, S. 1987. Sector context and performance - a comparison of industrial and government research units. Administration and Society, 19(2): 197-235.

Brewster, C., \& Mayrhofer, W. (Eds.) 2012. A handbook of research into comparative human resource management practice. Cheltenham, UK: Edward Elgar.

Brewster, C., Mayrhofer, W., \& Smale, A. 2016. Crossing the streams: HRM in multinational enterprises and comparative HRM. Human Resource Management Review, doi:http://dx.doi.org.ezaccess.libraries.psu.edu/10.1016/j.hrmr.2016.04.002.

Brewster, C., Wood, G., \& Brookes, M. 2008. Similarity, isomorphism or duality? Recent survey evidence on the human resource management policies of multinational corporations. British Journal of Management, 19(4): 320-342. 
Brewster, C., Wood, G., \& Goergen, M. 2015. Institutions, unionization and voice: The relative impact of context and actors on firm level practice. Economic and Industrial Democracy, 36(2): 195-214.

Brewster, C., Croucher, R., Wood, G., \& Brookes, M. 2007. Collective and Individual Voice: Convergence in Europe? International Journal of Human Resource Management, 18(7): 12461262.

Brislin, R. W. (Ed) 1976. Translation: Applications and research. New York, NY: Wiley.

Chung, C., Sparrow, P., \& Bozkurt, Ö. 2014. South Korean MNEs' international HRM approach: Hybridization of global standards and local practices. Journal of World Business, 49(4): 549-559.

Chung, H., \& Tijdens, K. 2013. Working time flexibility components and working time regimes in Europe: Using company level data across 21 countries. International Journal of Human Resource Management, 24(7): 1418-1434.

Colvin, A. J. S., \& Darbishire, O. 2013. Convergence in industrial relations institutions: The emerging Anglo-American model? Industrial and Labor Relations Review, 66(5): 1047-1077.

Craig, C. S., Douglas, S. P., \& Grein, A. 1992. Patterns of convergence and divergence among industrialized nations: 1960 - 1988. Journal of International Business Studies, 23(4): 773-787.

Crouch, C. 2005. Models of capitalism. New Political Economy, 10(4): 439-456.

Dacin, M. T., Goodstein, J., \& Scott, W. R. 2002. Institutional theory and institutional change: Introduction to the special research forum. Academy of Management Journal, 45(1), 45-57.

D'Arcimoles, C. H. 1997. Human resource policies and company performance: A quantitative approach using longitudinal data. Organization Studies, 18(5): 857-874.

DiMaggio, P. J., \& Powell, W. W. 1983. The iron cage revisited: Institutional isomorphism and collective rationality in organizational fields. American Sociological Review, 48(2): 147-60.

Dore, R. 2008. Financialization of the global economy. Industrial and Corporate Change, 17(6): 10971112.

Edwards, P. K., Sanchez-Mangas, R., Jalette, P., Lavelle, J., \& Minbaeva, D. 2016. Global standardization or national differentiation of HRM practices in multinational companies? A 
comparison of multinationals in five countries. Journal of International Business Studies, 47(8): $997-1021$.

Edwards, P. K., Sanchez-Mangas, R., Tregaskis, O., Levesque, C., McDonnell, A., \& Quintanilla, J. 2013. Human resource management practices in the multinational company: A test of system, societal, and dominance effects. Industrial \& Labor Relations Review, 66(3), 588-617.

Farndale, E., Brewster, C., \& Poutsma, E. 2008. Coordinated vs. liberal market HRM: the impact of institutionalization on multinational firms. International Journal of Human Resource Management, 19(11): 2004-2023.

Fay, C. H. 2008. The global convergence of compensation practices. In L. R. R. Gomez-Mejia and S. Werner (Eds.), Global compensation: 131-141. Oxon, UK: Routledge.

Fenton-O'Creevy, M., Gooderham, P., \& Nordhaug, O. 2008. Human resource management in US subsidiaries in Europe and Australia: Centralization or autonomy? Journal of International Business Studies, 39(1): 151-166.

Ferner, A., \& Quintanilla, J. 1998. Multinationals, National Business Systems and HRM: The Enduring Influence of National Identity or a Process of “Anglo-Saxonisation”. International Journal of Human Resource Management, 9(4): 710-31.

Festing, M. 2012. Strategic human resource management in Germany: evidence of convergence to the US model, the European model, or a distinctive national model? Academy of Management Perspectives, 26(2): 37-54.

Festing, M., Engle, A., Dowling, P., \& Sahakiants, I. 2012. HRM activities: Pay and rewards. In Brewster, C., \& Mayrhofer, W. (Eds.). A handbook of research into comparative human resource management practice: 139-163. Cheltenham, UK: Edward Elgar.

Festing, M., \& Sahakiants, I. 2010. Compensation practices in Central and Eastern European EU member states. An analytical framework based on institutional perspectives, path dependencies, and efficiency considerations. Thunderbird International Business Review, 52(3): 203-216. 
Gialis, S., \& Taylor, M. 2016. A regional account of flexibilization across the EU: The 'flexible contractual arrangements' composite index and the impact of recession. Social Indicators Research, 128(3): 1121-1146.

Goergen, M., Brewster, C., \& Wood, G. 2009. Corporate governance regimes and employment relations in Europe. Industrial Relations, 64(4): 620-640.

Goergen, M., Brewster, C., Wood, G. T., \& Wilkinson, A. 2012. Varieties of capitalism and investments in human capital. Industrial Relations, 51(2): 501-52.

Gooderham, P. N., \& Nordhaug, O. 2011. One European model of HRM? Cranet empirical contributions. Human Resource Management Review, 21(1): 1-10.

Gooderham, P. N., Nordhaug, O., \& Ringdal, K. 1999. Institutional and rational determinants of organizational practices: Human resource management in European firms. Administrative Science Quarterly, 44(3): 507-531.

Guest, D.E., Michie, J., Conway, N., \& Sheehan, M. 2003. Human resource management and corporate performance in the UK. British Journal of Industrial Relations, 41(2): 291-314.

Gunnigle, P., Murphy, K. R., Cleveland, J. N., Heraty, N., \& Morley, M. (2002). Localization in human resource management: Comparing American and European multinational corporations. Advances in Comparative International Management, 14: 259-284.

Hall, P. A., \& Soskice, D. (Eds) 2001. Varieties of capitalism: The institutional foundations of comparative advantage. Oxford, UK: Oxford University Press.

Hall, P. A., \& Thelen, K. 2009. Institutional change in varieties of capitalism. Socio-Economic Review, 7(1): 7-34.

Höpner, M. 2005. What connects industrial relations and corporate governance: explaining institutional complementarity. Socio-Economic Review, 3(2): 331-358.

Hotho, J. J. 2014. From typology to taxonomy: A configurational analysis of national business systems and their explanatory power. Organization Studies, 35(5): 671-702. 
Huo, Y. P., Huang, H. J., \& Napier, N. K. 2002. Divergence or convergence: A cross-national comparison of personnel selection practices. Human Resource Management, 41(1): 31-44.

Huselid, M., \& Becker, B. E. 2000. Comment on 'Measurement error in research on human resources and firm performance: how much error is there and how does it influence effect size estimates?' By Gerhart, Wright, McMahan, and Snell. Personnel Psychology, 53(4): 835-854.

Jackson, G., \& Deeg, R. 2008. Comparing capitalisms: understanding institutional diversity and its implication for international business. Journal of International Business Studies, 39(4): 540-561.

Kalmi, P., Pendleton, A., \& Poutsma, E. 2012. Bargaining regimes, variable pay and financial participation: some survey evidence on pay determination. International Journal of Human Resource Management, 23(8): 1643-1659.

Kalleberg, A. 2003. Flexible firms and labor market segmentation: Effects of workplace restructuring on jobs and workers. Work and Occupations, 30(2): 154-175.

Katz, H. C. 1993. The decentralization of collective bargaining: A literature review and comparative analysis. Industrial and Labor Relations Review, 47(1): 3-22.

Kaufman, B. E. 2007. The institutional economics of John R Commons: Complement and substitute for neoclassical economic theory. Socio-Economic Review, 5(1): 3-45.

Kaufman, B. E. 2016. Globalization and convergence-divergence of HRM across nations: New measures, explanatory theory, and non-standard predictions from bringing in economics. Human Resource Management Review, 26(4): 338-351.

Kerr, C., Dunlop, J. T., Harbison, F., \& Meyers, C. A. 1960. Industrialism and industrial man. The problems of labor and management in economic growth. Cambridge, MA: Harvard University Press.

Kessler, I., Undy, R., \& Heron, P. 2004. Employee perspectives on communication and consultation: Findings from a cross-national survey. International Journal of Human Resource Management, 15(3): 512-532. 
Kostova, T., \& Roth, K. 2002. Adoption of an organizational practice by subsidiaries of multinational corporations: Institutional and relational effects. Academy of Management Journal, 45(1): 215233.

Kostova, T., \& Zaheer, S. 1999. Organizational legitimacy under conditions of complexity: The case of the multinational enterprise. Academy of Management Review, 24(1): 64-81.

Kostova, T., Roth, K., \& Dacin, M. T. 2008. Institutional theory in the study of multinational corporations: A critique and new directions. Academy of Management Review, 33(4), 994-1006.

Lawler, J. L., Chen, S., Wu, P., Bae, J., \& Bai, B. 2011. High-performance work systems in foreign subsidiaries of American multinationals: An institutional model. Journal of International Business Studies, 42(2): 202-220.

Looise, J. K., \& Drucker, M. 2002. Employee participation in multinational enterprises. The effects of globalisation on Dutch works councils. Employee Relations, 24(1): 29-52.

Marginson, P., Sisson, K., \& Arrowsmith, J. 2003. Between decentralization and Europeanization: Sectoral bargaining in four countries and two sectors. European Journal of Industrial Relations, 9(2): 163-187.

Mayrhofer, W., Brewster, C., Morley, M. J., \& Ledolter, J. 2011. Hearing a different drummer? Convergence of human resource management in Europe - A longitudinal analysis. Human Resource Management Review, 21(1): 50-67.

Mayrhofer, W., Müller-Camen, M., Ledolter, J., Strunk, G., \& Erten, C. (2002). The Diffusion of Management Concepts in Europe - Conceptual Considerations and Longitudinal Analysis. Journal of Cross-Cultural Competence \& Management, 3, 315-349.

Menard, S. 2007. Handbook of longitudinal research: Design, methods, and analyses. Burlington, MA: Elsevier.

Morley, M., Brewster, C., Gunnigle, P., \& Mayrhofer, W. 1996. Evaluating change in European industrial relations: Research evidence on trends at organizational level. International Journal of Human Resource Management, 7(3): 640-656. 
Nikandrou, I., Apospori, E., \& Papalexandris, N. 2005. Changes in HRM in Europe: A longitudinal study among 18 European countries. Journal of European Industrial Training, 29(7): 541-560.

North, D. C. 1990. Institutions, institutional change and economic performance. Cambridge, UK: Cambridge University Press.

Pendelton, A., \& Poutsma, E. 2012. Financial participation. In C. Brewster \& W. Mayrhofer (Eds.), Handbook of research on comparative human resource management: 345-369. London, UK: Edward Elgar.

Perlmutter, H. V. (1969). The Tortuous Evolution of the Multinational Corporation. Columbia Journal of World Business, 4(1), 9-18.

Poor, J., Karoliny, Z., Alas, R., \& Vatchkova, E. K. 2011. Comparative international human resource management (CIHRM) in the light of the cranet regional research survey in transitional economies. Employee Relations, 33(4): 428-443.

Poutsma, E., Ligthart, P. E. M., \& Schouteten, R. 2005. Employee share schemes in Europe. The influence of US multinationals. Management Revue, 16(1): 99-122.

Poutsma, E., Ligthart, P. E. M., \& Veersma, U. (2006). The diffusion of calculative and collaborative HRM practices in European firms. Industrial Relations, 45(4), 513-546.

Pudelko, M., \& Harzing, A. 2007. Country-of-origin, localization, or dominance effect? An empirical investigation of HRM practices in foreign subsidiaries. Human Resource Management, 46(4): $535-559$.

Pudelko, M., \& Harzing, A. 2008. The golden triangle for MNCs: Standardization towards headquarters practices, standardization towards global best practices, and localization. Organizational Dynamics, 37(4): 394-404.

Rabe-Hesketh, S., \& Skrondal, A. 2005. Multilevel and longitudinal modeling using Stata (1st ed.). College Station, TX: Stata Press.

Rabe-Hesketh S., Skrondal A., \& Pickles, A. 2004. GLLAMM Manual. U.C. Berkeley Division of Biostatistics Working Paper Series, 160. 
Rosenzweig, P. M., \& Nohria, N. 1994. Influences on human resource management practices in multinational corporations. Journal of International Business Studies, 25(2): 229-251.

Rosenzweig, P. M., \& Singh, J. V. 1991. Organizational environments and the multinational enterprise. Academy of Management Review, 16(2): 340-361.

Rugman, A. M., \& Verbeke, A. 2001. Subsidiary-specific advantages in multinational enterprises. Strategic Management Journal, 22(3): 237-250.

Saka-Helmhout, A., Deeg, R., \& Greenwood, R. 2016. The MNE as a challenge to institutional theory: Key concepts, recent developments and empirical evidence. Journal of Management Studies, 53(1): 1-11.

Schnabel, C., Zagelmeyer, S., \& Kohaut, S. 2006. Collective bargaining structure and its determinants: An empirical analysis with British and German establishment data. European Journal of Industrial Relations, 12(2): 165-188.

Schneider, M. R., \& Paunescu, M. 2012. Changing varieties of capitalism and revealed comparative advantages from 1990 to 2005: a test of the Hall and Soskice claims. Socio-Economic Review, 10 (4): 731-753.

Scott, W. R., \& Meyer, J. W. 1994. Institutional environments and organizations: structural complexity and individualism. Thousand Oaks, CA: Sage.

Scott, W. R. 2001. Institutions and organizations ( $2^{\text {nd }}$ ed.). Thousand Oaks, CA: Sage.

Snijders, T., \& Bosker, R. 1999. Multilevel analysis: an introduction to basic and applied multilevel analysis. London, UK: Sage.

Tempel, A., \& Walgenbach, P. 2007. Global standardization of organizational forms and management practices? What new institutionalism and the business-systems approach can learn from each other. Journal of Management Studies, 44(1), 1-24.

Thelen, K. 2001. Varieties of labor politics in the developed democracies. In P. A. Hall, \& D. Soskice (Eds), Varieties of capitalism: The institutional foundations of comparative advantage: 71-103. Oxford, UK: Oxford University Press. 
Thelen, K. 2004. How institutions evolve: The political economy of skills in Germany, Britain, the United States and Japan. Cambridge: Cambridge University Press.

Thelen, K. 2014. Varieties of liberalization and the new politics of social solidarity. Cambridge: Cambridge University Press.

Thornton, P. H., Ocasio, W., \& Lounsbury, M. 2012. The institutional logics perspective: A new approach to culture, structure and process. Oxford, UK: Oxford University Press.

Traxler, F., Arrowsmith, J., Nergaard, K., \& Molins Lopez-Rodo, J. 2008. Variable pay and collective bargaining: A cross-national comparison of the banking sector. Economic and Industrial Democracy, 29: 406-431.

Tregaskis, O., \& Brewster, C. 2006. Converging or diverging? A comparative analysis of trends in contingent employment practice in Europe over a decade. Journal of International Business Studies, 37(1): 111-126.

Tregaskis, O., \& Heraty, N. 2012. Human resource development: national embeddedness. In C. Brewster \& W. Mayrhofer (Eds.), Handbook of research on comparative human resource management: 164-184. London, UK: Edward Elgar.

Williams, C. C., \& Padmore, J. 2013. Evaluating the prevalence and distribution of quasi-formal employment in Europe. Industrial Relations, 68(1): 71-94. 
TABLE 1

Longitudinal multi-country studies of HRM practice convergence using Cranet data

\begin{tabular}{|c|c|c|c|c|c|c|}
\hline Study & $\begin{array}{l}\text { HRM practice } \\
\text { area }\end{array}$ & $\begin{array}{l}\text { Countries } \\
\text { included }\end{array}$ & $\begin{array}{l}\text { Data } \\
\text { collection } \\
\text { rounds }\end{array}$ & Research aims & Analysis & Conclusions \\
\hline $\begin{array}{l}\text { Morley, } \\
\text { Brewster, } \\
\text { Gunnigle, \& } \\
\text { Mayrhofer } \\
\text { (1996) }\end{array}$ & $\begin{array}{l}\text { trade union } \\
\text { membership, } \\
\text { recognition and } \\
\text { influence, policy } \\
\text { determination } \\
\text { locus }\end{array}$ & $\begin{array}{l}13 \\
\text { European } \\
\text { countries }\end{array}$ & $\begin{array}{l}\text { 1990/91, } \\
1992,1995\end{array}$ & $\begin{array}{l}\text { To investigate a number of key } \\
\text { aspects of industrial relations at } \\
\text { the level of the employing } \\
\text { organization as a means of } \\
\text { evaluating developments in the } \\
\text { nature and conduct of industrial } \\
\text { relations. }\end{array}$ & $\begin{array}{l}\text { Comparison of } \\
\text { statistics per } \\
\text { year to signal } \\
\text { trends but no } \\
\text { significance } \\
\text { testing of } \\
\text { differences to } \\
\text { explore } \\
\text { convergence }\end{array}$ & $\mathrm{n} / \mathrm{a}$ \\
\hline $\begin{array}{l}\text { Nikandrou, } \\
\text { Apospori, \& } \\
\text { Papalexandri } \\
(2005)\end{array}$ & $\begin{array}{l}\text { Broad range of } \\
\text { HRM } \\
\text { department } \\
\text { measures and } \\
\text { HRM practices }\end{array}$ & $\begin{array}{l}18 \\
\text { European } \\
\text { countries }\end{array}$ & $\begin{array}{l}2 \text { rounds: } \\
1995,1999- \\
2000\end{array}$ & $\begin{array}{l}\text { To examine whether a change } \\
\text { toward more similarities in HRM } \\
\text { exists in Europe. To identify } \\
\text { country-specific changes which } \\
\text { may account for a country's } \\
\text { transfer from the periphery closer } \\
\text { to a cluster, or from one cluster to } \\
\text { another. }\end{array}$ & $\begin{array}{l}\text { Cluster } \\
\text { analysis at the } \\
\text { country level } \\
\text { of analysis }\end{array}$ & $\begin{array}{l}\text { "the two clusters do not show } \\
\text { any considerable change } \\
\text { towards convergence" (p. 549). }\end{array}$ \\
\hline $\begin{array}{l}\text { Tregaskis \& } \\
\text { Brewster } \\
(2006)\end{array}$ & $\begin{array}{l}\text { Part-time, } \\
\text { temporary, and } \\
\text { fixed-term } \\
\text { contracts }\end{array}$ & $\begin{array}{l}5 \\
\text { European } \\
\text { countries }\end{array}$ & $\begin{array}{l}3 \text { rounds: } \\
1991,1995, \\
1999-2000\end{array}$ & $\begin{array}{l}\text { To examine the extent of use of } \\
\text { time/ temporary/ fixed-term } \\
\text { contracts between organizations } \\
\text { operating in different countries } \\
\text { over time. }\end{array}$ & $\begin{array}{l}\text { MANOVA } \\
\text { analysis for } \\
\text { planned } \\
\text { contrasts to } \\
\text { test for the } \\
\text { effect of } \\
\text { country }\end{array}$ & $\begin{array}{l}\text { "There is no evidence that } \\
\text { either the regional institutional } \\
\text { pressures coming from the } \\
\text { European Commission or } \\
\text { regional or global competitive } \\
\text { pressures are creating "final' } \\
\text { convergence in organizational } \\
\text { practice" (p. 122). }\end{array}$ \\
\hline $\begin{array}{l}\text { Brewster, } \\
\text { Croucher, } \\
\text { Wood, \& } \\
\text { Brookes } \\
(2007)\end{array}$ & $\begin{array}{l}\text { collective } \\
\text { representation } \\
\text { mechanisms }\end{array}$ & $\begin{array}{l}3 \\
\text { European } \\
\text { countries }\end{array}$ & $\begin{array}{l}4 \text { rounds: } \\
\text { 1991, 1995, } \\
1999-2000 \\
2004-05\end{array}$ & $\begin{array}{l}\text { To explore the general trend away } \\
\text { from collective and towards } \\
\text { individual voice mechanisms, } \\
\text { reflecting a predominant } \\
\text { trajectory of managerial practices }\end{array}$ & $\begin{array}{l}\text { Estimating } \\
\text { and comparing } \\
\text { probabilities } \\
\text { of practice use }\end{array}$ & $\begin{array}{l}\text { "Our analysis gives the } \\
\text { convergence argument some } \\
\text { limited support in that German } \\
\text { organizations, controlling for } \\
\text { differences in size and sector, }\end{array}$ \\
\hline
\end{tabular}




\begin{tabular}{|c|c|c|c|c|c|c|}
\hline & & & & $\begin{array}{l}\text { towards convergence with the } \\
\text { liberal market model. }\end{array}$ & $\begin{array}{l}\text { at country } \\
\text { level }\end{array}$ & $\begin{array}{l}\text { show a decreasing tendency to } \\
\text { use their works councils" (p. } \\
\text { 1259) }\end{array}$ \\
\hline $\begin{array}{l}\text { Goergen, } \\
\text { Brewster \& } \\
\text { Wood } \\
(2009)\end{array}$ & $\begin{array}{l}\text { Trade union } \\
\text { membership/ } \\
\text { influence }\end{array}$ & $\begin{array}{l}\text { Western } \\
\text { European } \\
\text { countries }\end{array}$ & $\begin{array}{l}3 \text { rounds: } \\
1995, \\
1999-2000, \\
2004-05\end{array}$ & $\begin{array}{l}\text { To test relationships between } \\
\text { institutions, corporate } \\
\text { governance, and union power. }\end{array}$ & $\begin{array}{l}\text { Logit } \\
\text { regression } \\
\text { analyses based } \\
\text { on country- } \\
\text { level legal } \\
\text { traditions }\end{array}$ & $\begin{array}{l}\text { "the strongest indicator of } \\
\text { union strength was national } \\
\text { legal tradition, suggesting a } \\
\text { significant degree of path } \\
\text { dependence" (p. 632) }\end{array}$ \\
\hline $\begin{array}{l}\text { Goergen, } \\
\text { Brewster, } \\
\text { Wood \& } \\
\text { Wilkinson } \\
(2012)\end{array}$ & $\begin{array}{l}\text { training days, } \\
\text { training spend }\end{array}$ & $\begin{array}{l}18 \\
\text { European } \\
\text { countries }\end{array}$ & $\begin{array}{l}4 \text { rounds: } \\
\text { 1991, 1995, } \\
\text { 1999-2000, } \\
2004-05\end{array}$ & $\begin{array}{l}\text { To explore the relationship } \\
\text { between national institutional } \\
\text { archetypes and investments in } \\
\text { training and development based } \\
\text { on varieties of capitalism } \\
\text { theorizing. }\end{array}$ & $\begin{array}{l}\text { Cluster } \\
\text { analysis at the } \\
\text { organization } \\
\text { level of } \\
\text { analysis }\end{array}$ & $\begin{array}{l}\text { "specific national realities are } \\
\text { associated with specific firm- } \\
\text { level practices, underscoring } \\
\text { the existence of clear } \\
\text { alternative clusters of } \\
\text { institutions and practices" (p. } \\
\text { 523) }\end{array}$ \\
\hline $\begin{array}{l}\text { Mayrhofer, } \\
\text { Brewster, } \\
\text { Morley \& } \\
\text { Ledolter } \\
\text { (2011) }\end{array}$ & $\begin{array}{l}\text { HRM practice } \\
\text { bundles: } \\
\text { development, } \\
\text { reward, } \\
\text { communication, } \\
\text { plus HRM } \\
\text { responsibilities, } \\
\text { HRM-staff ratio }\end{array}$ & $\begin{array}{l}13 \\
\text { European } \\
\text { countries }\end{array}$ & $\begin{array}{l}4 \text { rounds: } \\
\text { 1992, 1995, } \\
\text { 1999-2000, } \\
2004-05\end{array}$ & $\begin{array}{l}\text { To analyze empirically the } \\
\text { development of HRM in private } \\
\text { sector firms in } 13 \text { European } \\
\text { countries between } 1992 \text { and } 2004 \text {, } \\
\text { not only examining the extent of } \\
\text { convergence in HRM in Europe, } \\
\text { but also exploring the theoretical } \\
\text { implications for the interplay } \\
\text { between convergence and } \\
\text { divergence. }\end{array}$ & $\begin{array}{l}\text { Comparison } \\
\text { over time at } \\
\text { country level } \\
\text { of the use of } \\
\text { bundles of } \\
\text { practices } \\
\text { (likelihood } \\
\text { ratios) }\end{array}$ & $\begin{array}{l}\text { "We find considerable evidence } \\
\text { of directional similarity - } \\
\text { practices increasing or } \\
\text { decreasing in the same way } \\
\text { across the countries - but no } \\
\text { evidence of final convergence - } \\
\text { countries becoming more alike } \\
\text { in the way they manage } \\
\text { people" (p. 50) }\end{array}$ \\
\hline $\begin{array}{l}\text { Poor, } \\
\text { Karoliny, } \\
\text { Alas, \& } \\
\text { Vatchkova, } \\
(2011)\end{array}$ & $\begin{array}{l}\text { training, and } \\
\text { role of the HRM } \\
\text { department }\end{array}$ & $\begin{array}{l}3 \text { Central } \\
\text { and } \\
\text { Eastern } \\
\text { European } \\
\text { countries }\end{array}$ & $\begin{array}{l}3 \text { rounds: } \\
1995, \\
1999-2000 \\
2004-05\end{array}$ & $\begin{array}{l}\text { To draw attention to the } \\
\text { similarities in the historical } \\
\text { background and in the transitional } \\
\text { period of the post-socialist CEE } \\
\text { (Central and East European) } \\
\text { countries related to the } \\
\text { modernization of the HRM } \\
\text { function. }\end{array}$ & $\begin{array}{l}\text { Comparison of } \\
\text { statistics per } \\
\text { year to signal } \\
\text { trends but no } \\
\text { significance } \\
\text { testing of } \\
\text { differences to } \\
\text { explore } \\
\text { convergence }\end{array}$ & $\mathrm{n} / \mathrm{a}$ \\
\hline
\end{tabular}


TABLE 2

Respondent characteristics

\begin{tabular}{|c|c|c|c|}
\hline Country & Per cent & Mean & SD \\
\hline United Kingdom & 24.67 & & \\
\hline Australia & 6.39 & & \\
\hline Germany & 18.77 & & \\
\hline Sweden & 9.73 & & \\
\hline Denmark & 13.53 & & \\
\hline Netherlands & 4.61 & & \\
\hline Finland & 5.45 & & \\
\hline Austria & 7.70 & & \\
\hline Belgium & 9.14 & & \\
\hline \multicolumn{4}{|l|}{ Year } \\
\hline $1999 / 2000$ & 41.56 & & \\
\hline $2004 / 05$ & 37.77 & & \\
\hline $2009 / 10$ & 20.67 & & \\
\hline \multicolumn{4}{|l|}{ Industry } \\
\hline Construction & 4.56 & & \\
\hline Transportation & 5.26 & & \\
\hline Banking and finance & 11.58 & & \\
\hline Chemicals & 7.73 & & \\
\hline Other industries & 29.24 & & \\
\hline Manufacturing & 41.63 & & \\
\hline \multicolumn{4}{|l|}{ Trade union membership } \\
\hline $0 \%$ & 11.84 & & \\
\hline $1-25 \%$ & 24.53 & & \\
\hline $26-50 \%$ & 13.09 & & \\
\hline $51-75 \%$ & 15.46 & & \\
\hline $76-100 \%$ & 18.67 & & \\
\hline missing & 16.40 & & \\
\hline \multicolumn{4}{|l|}{ Economy } \\
\hline CME & 68.94 & & \\
\hline LME & 31.06 & & \\
\hline \multicolumn{4}{|l|}{ Organization type } \\
\hline Indigenous & 53.20 & & \\
\hline Foreign MNE subsidiary & 46.80 & & \\
\hline \multicolumn{4}{|l|}{ Organization size } \\
\hline $\operatorname{Size}(\mathrm{Ln})$ & & 6.33 & 1.20 \\
\hline Size (median) & & 445.00 & \\
\hline
\end{tabular}


TABLE 3

HRM practices descriptive statistics

HRM areas and practices ${ }^{(a)}$

Level of wage bargaining

National/regional level wage bargaining

Company/establishment level wage

bargaining

Site level wage bargaining

Individual level wage bargaining

\section{Compensation}

Share ownership

Profit sharing

Group bonuses

Performance related pay

\section{Contingent employment}

$>10 \%$ of workforce on part-time contracts

$>0 \%$ of workforce on temporary contracts

$>0 \%$ of workforce on fixed-term contracts

\section{Information provision}

Workforce briefing on financial performance $^{(b)}$

Workforce briefing on strategy ${ }^{(b)}$

Written mission statement

Written corporate strategy

\section{Training}

Percentage of payroll costs spent on training

Number of training days received by employees $^{(\mathrm{c})}$

\begin{tabular}{|c|c|c|c|c|}
\hline $\begin{array}{c}1999- \\
2000\end{array}$ & $\begin{array}{c}2004- \\
2005\end{array}$ & $\begin{array}{c}2009- \\
2010\end{array}$ & Total $^{(d)}$ & $\mathbf{n}$ \\
\hline $57.7 \%$ & $59.3 \%$ & $69.9 \%$ & $60.84 \%$ & 5,743 \\
\hline $43.1 \%$ & $55.6 \%$ & $37.2 \%$ & $46.61 \%$ & 5,743 \\
\hline $35.3 \%$ & $36.7 \%$ & $40.2 \%$ & $36.84 \%$ & 5,743 \\
\hline $70.0 \%$ & $72.6 \%$ & $84.0 \%$ & $73.88 \%$ & 5,743 \\
\hline $29.4 \%$ & $40.6 \%$ & $33.4 \%$ & $34.44 \%$ & 5,743 \\
\hline $40.4 \%$ & $42.7 \%$ & $41.9 \%$ & $41.58 \%$ & 5,743 \\
\hline $35.8 \%$ & $37.4 \%$ & $59.9 \%$ & $41.37 \%$ & 5,743 \\
\hline $59.8 \%$ & $54.4 \%$ & $78.0 \%$ & $61.55 \%$ & 5,743 \\
\hline $17.1 \%$ & $26.4 \%$ & $34.9 \%$ & $24.29 \%$ & 5,596 \\
\hline $57.9 \%$ & $80.5 \%$ & $81.7 \%$ & $71.51 \%$ & 5,515 \\
\hline $53.0 \%$ & $76.1 \%$ & $81.2 \%$ & $67.70 \%$ & 5,511 \\
\hline $81.0 \%$ & $83.5 \%$ & $80.7 \%$ & $81.87 \%$ & 5,743 \\
\hline $60.2 \%$ & $72.3 \%$ & $75.5 \%$ & $67.93 \%$ & 5,743 \\
\hline $79.5 \%$ & $81.5 \%$ & $83.2 \%$ & $81.00 \%$ & 5,679 \\
\hline $76.0 \%$ & $80.4 \%$ & $81.3 \%$ & $78.76 \%$ & 5,684 \\
\hline $61.3 \%$ & $56.6 \%$ & $78.3 \%$ & $63.72 \%$ & 4,316 \\
\hline $87.9 \%$ & $89.0 \%$ & $90.1 \%$ & $88.71 \%$ & 3,993 \\
\hline
\end{tabular}

(a) Dichotomous items unless otherwise indicated - practice adopted (1) versus no practice adopted (0).

(b) To employees beyond management alone.

(c) Other than management.

(d) Percentage of organizations reporting the presence of a practice (across all years combined). 
TABLE 4

Spearman's correlations of HRM practice variables

1. National/regional

level wage

bargaining

2. Company level wage bargaining $-0.10^{*}$

3. Site level wage bargaining

4. Individual level wage bargaining

$-0.05^{*} \quad 0.06^{*}$

$0.20^{*}-0.21^{*}$

wage bargaining

6. Profit sharing

7. Group bonus

8. Performance related pay

9. Part-time contracts

10. Temporary contracts

11. Fixed-term contracts

12. Financial performance briefing

13. Strategy Briefing

14. Mission statement

15. Corporate strategy

16. Training spend

17. Training days

$-0.07^{*} \quad 0.09^{*}$

$\begin{array}{llll}-0.02 & 0.04^{*} & 0.08^{*} & 0.09^{*}\end{array}$

$\begin{array}{lll}0.02 & 0.07^{*} & 0.07^{*}\end{array}$

0.03

$0.04^{*}$

$0.07^{*}$

0.03

$0.16^{*}$

0.02

$-0.01$

$-0.05^{*}$

$0.08^{*}$

$0.15^{*}$

0.02

0.00

0.0

$0.07^{*}$

0.02

$0.04^{*}$

$-0.05^{*}$

$-0.03$

$-0.04$

0.30

0.03

$0.04^{*} \quad 0.05^{*}$

$-0.02$

0.03

0.02

$-0.02$

$-0.01$

0.0

$0.08^{*} \quad 0.03$

$0.02 \quad 0.00$

$0.05^{*} \quad 0.02$

$0.04^{*} \quad 0.03$

$\begin{array}{cc}0.04 & 0.03 \\ 0.02 & 0.03\end{array}$

$-0.02$

$0.10^{*}$

$-0.05^{*}$

0.01

0.00

$\mathrm{p}<0.05 . \mathrm{n}=3,993$ to 5,743 . 
TABLE 5

Trend categorizations

\begin{tabular}{|l|l|l|l|l|}
\hline & Trend & $\begin{array}{l}\text { Baseline } \\
\mathbf{( 2 0 0 9 - 1 0 )}\end{array}$ & Preceding years & Description \\
\hline 1 & $\begin{array}{l}\text { Constant no } \\
\text { difference }\end{array}$ & No difference & $\begin{array}{l}\text { No difference in either } \\
\text { preceding year }\end{array}$ & $\begin{array}{l}\text { No changing trend observed, ending } \\
\text { with no significant difference }\end{array}$ \\
\hline 2 & $\begin{array}{l}\text { Robust } \\
\text { convergence }\end{array}$ & No difference & Decreasing differences & $\begin{array}{l}\text { Stable trend of diminishing difference } \\
\text { over time ending in no significant } \\
\text { difference }\end{array}$ \\
\hline 3 & $\begin{array}{l}\text { Non-robust } \\
\text { convergence }\end{array}$ & No difference & $\begin{array}{l}\text { Mix of decreasing/ } \\
\text { increasing differences }\end{array}$ & $\begin{array}{l}\text { Irregular trend of difference over time } \\
\text { ending in no significant difference }\end{array}$ \\
\hline 4 & $\begin{array}{l}\text { Non-robust } \\
\text { divergence }\end{array}$ & Difference & $\begin{array}{l}\text { Mix of increasing/ } \\
\text { decreasing differences }\end{array}$ & $\begin{array}{l}\text { Irregular trend of difference over time } \\
\text { ending in significant difference }\end{array}$ \\
\hline 5 & $\begin{array}{l}\text { Robust } \\
\text { divergence }\end{array}$ & Difference & Increasing differences & $\begin{array}{l}\text { Stable trend of increasing difference } \\
\text { over time ending in significant } \\
\text { difference }\end{array}$ \\
\hline 6 & $\begin{array}{l}\text { Constant } \\
\text { difference }\end{array}$ & Difference & $\begin{array}{l}\text { No difference in either } \\
\text { preceding year }\end{array}$ & $\begin{array}{l}\text { No changing trend observed, ending } \\
\text { with a significant difference }\end{array}$ \\
\hline
\end{tabular}


TABLE 6

Odds-ratios of conditional effects of market economy on the use of HRM practices over time

\begin{tabular}{|c|c|c|c|c|}
\hline \multirow[t]{2}{*}{ Practice } & \multirow{2}{*}{$\frac{\text { Simple effect }}{\text { LME }}$} & \multicolumn{2}{|c|}{ Interaction effects } & \multirow[t]{2}{*}{ Trend } \\
\hline & & $\begin{array}{l}\text { LME x } \\
\text { 2004-05 }\end{array}$ & $\begin{array}{c}\text { LME x } \\
\text { 1999-2000 }\end{array}$ & \\
\hline $\begin{array}{l}\text { National level wage } \\
\text { bargaining }\end{array}$ & 0.22 & $1.71^{*}$ & 1.35 & Non-robust convergence \\
\hline $\begin{array}{l}\text { Company level wage } \\
\text { bargaining }\end{array}$ & $4.49^{* *}$ & $0.30^{*}$ & 1.01 & Non-robust divergence \\
\hline $\begin{array}{l}\text { Site level wage } \\
\text { bargaining }\end{array}$ & 0.80 & 1.89 & $2.10^{*}$ & Robust convergence \\
\hline $\begin{array}{l}\text { Individual level wage } \\
\text { bargaining }\end{array}$ & $0.37^{*}$ & 1.13 & 1.04 & Constant difference \\
\hline Share ownership & $2.70^{* *}$ & $0.43^{* *}$ & 0.86 & Non-robust divergence \\
\hline Profit sharing & 0.46 & 0.79 & $1.90^{*}$ & Robust convergence \\
\hline Group bonus & $1.96^{* *}$ & $0.30^{* *}$ & 1.10 & Non-robust divergence \\
\hline Performance related pay & 1.31 & $0.45^{* *}$ & 1.10 & Non-robust convergence \\
\hline $\begin{array}{l}>10 \% \text { part-time } \\
\text { contracts }\end{array}$ & 0.70 & 0.75 & 0.75 & Constant no difference \\
\hline $\begin{array}{l}>0 \% \text { temporary } \\
\text { contracts }\end{array}$ & 0.45 & $5.27^{*}$ & $6.10^{*}$ & Robust convergence \\
\hline $\begin{array}{l}>0 \% \text { fixed-term } \\
\text { contracts }\end{array}$ & 0.65 & 0.81 & 0.58 & Constant no difference \\
\hline $\begin{array}{l}\text { Briefing on financial } \\
\text { performance }\end{array}$ & 0.66 & 0.97 & 0.99 & Constant no difference \\
\hline Briefing on strategy & 0.71 & 1.46 & 0.99 & Constant no difference \\
\hline $\begin{array}{l}\text { Written mission } \\
\text { statement }\end{array}$ & 0.71 & 0.70 & 1.26 & Constant no difference \\
\hline $\begin{array}{l}\text { Written corporate } \\
\text { strategy }\end{array}$ & 0.58 & 1.26 & 2.11 & Constant no difference \\
\hline Training spend & 0.73 & 1.51 & 1.45 & Constant no difference \\
\hline Training days & 0.63 & 1.18 & 1.44 & Constant no difference \\
\hline
\end{tabular}

Notes: ${ }^{* *} \mathrm{p}<0.01,{ }^{*} \mathrm{p}<0.05$ using robust standard errors; Effects tested under conditions of: CME, 2009-10, Indigenous. 
TABLE 7

Odds-ratios of conditional effects of organization type on the use of HRM practices over time

\begin{tabular}{|c|c|c|c|c|}
\hline \multirow[t]{2}{*}{ Practice } & \multirow{2}{*}{$\begin{array}{r}\text { Simple effect } \\
\text { Foreign }\end{array}$} & \multicolumn{2}{|c|}{ Interaction effects } & \multirow[t]{2}{*}{ Trend } \\
\hline & & $\begin{array}{c}\text { Foreign } x \\
2004-05 \\
\end{array}$ & $\begin{array}{l}\text { Foreign } x \\
1999-2000 \\
\end{array}$ & \\
\hline $\begin{array}{l}\text { National level wage } \\
\text { bargaining }\end{array}$ & $0.68^{* *}$ & $1.29^{*}$ & 1.26 & Non-robust divergence \\
\hline $\begin{array}{l}\text { Company level wage } \\
\text { bargaining }\end{array}$ & $1.50^{*}$ & 0.81 & 1.11 & Constant difference \\
\hline Site level wage bargaining & $1.30^{*}$ & 1.00 & 1.14 & Constant difference \\
\hline $\begin{array}{l}\text { Individual level wage } \\
\text { bargaining }\end{array}$ & 1.33 & 0.82 & 0.80 & Constant no difference \\
\hline Share ownership & $2.79^{* *}$ & 0.85 & 0.74 & Constant difference \\
\hline Profit sharing & 1.20 & 1.07 & 1.20 & Constant no difference \\
\hline Group bonus & $2.16^{* *}$ & $0.49^{* *}$ & 0.75 & Non-robust divergence \\
\hline Performance related pay & $2.14^{* *}$ & 0.69 & 0.84 & Constant difference \\
\hline$>10 \%$ part-time contracts & $0.57^{* *}$ & 1.26 & 0.79 & Constant difference \\
\hline$>0 \%$ temporary contracts & 1.27 & 0.87 & 1.12 & Constant no difference \\
\hline$>0 \%$ fixed-term contracts & 1.29 & 0.85 & 0.98 & Constant no difference \\
\hline $\begin{array}{l}\text { Briefing on financial } \\
\text { performance }\end{array}$ & $1.51^{*}$ & 0.77 & 1.02 & Constant no difference \\
\hline Briefing on strategy & $1.40^{*}$ & 1.12 & $0.83^{*}$ & Non-robust divergence \\
\hline Written mission statement & 1.01 & 1.19 & $1.71^{*}$ & Robust convergence \\
\hline Written corporate strategy & 1.25 & 1.09 & $1.52^{* *}$ & Robust convergence \\
\hline Training spend & 0.92 & 1.04 & 1.26 & Constant no difference \\
\hline Training days & 1.07 & 1.05 & 1.47 & Constant no difference \\
\hline
\end{tabular}

Notes: ${ }^{* *} \mathrm{p}<0.01,{ }^{*} \mathrm{p}<0.05$ using robust standard errors; Effects tested under conditions of: Indigenous, 2009-10, CME. 
TABLE 8

Odds-ratios of conditional interaction effects of market economy and organization type on the use of HRM practices over time

\begin{tabular}{|c|c|c|c|c|}
\hline Practice & $\begin{array}{l}\text { LME x } \\
\text { Foreign }\end{array}$ & $\begin{array}{c}\text { LME x } \\
\text { Foreign } x \\
2004-05\end{array}$ & $\begin{array}{c}\text { LME x } \\
\text { Foreign x } \\
\text { 1999-2000 }\end{array}$ & Trend \\
\hline $\begin{array}{l}\text { National level wage } \\
\text { bargaining }\end{array}$ & 1.14 & $0.54^{* *}$ & 0.69 & Non-robust convergence \\
\hline $\begin{array}{l}\text { Company level wage } \\
\text { bargaining }\end{array}$ & 0.64 & 0.99 & 0.69 & Constant no difference \\
\hline Site level wage bargaining & $0.74^{* * *}$ & 1.70 & 1.00 & Constant difference \\
\hline $\begin{array}{l}\text { Individual level wage } \\
\text { bargaining }\end{array}$ & 1.27 & 0.65 & 0.78 & Constant no difference \\
\hline Share ownership & $0.45^{* *}$ & $1.77^{* * *}$ & $2.23^{* *}$ & Non-robust divergence \\
\hline Profit sharing & 0.49 & 1.55 & 1.45 & Constant no difference \\
\hline Group bonus & 0.88 & 1.00 & 1.11 & Constant no difference \\
\hline Performance related pay & 0.75 & 1.00 & 1.30 & Constant no difference \\
\hline$>10 \%$ part-time contracts & $0.57^{*}$ & $1.76^{*}$ & 1.67 & Non-robust divergence \\
\hline$>0 \%$ temporary contracts & $2.27^{*}$ & $0.40^{* *}$ & 0.48 & Non-robust divergence \\
\hline$>0 \%$ fixed-term contracts & 1.82 & 0.42 & 0.63 & Constant no difference \\
\hline $\begin{array}{l}\text { Briefing on financial } \\
\text { performance }\end{array}$ & 0.95 & 1.21 & 1.26 & Constant no difference \\
\hline Briefing on strategy & $1.52^{*}$ & $0.41^{* *}$ & 0.94 & Non-robust divergence \\
\hline Written mission statement & 1.46 & 0.77 & 0.55 & Constant no difference \\
\hline Written corporate strategy & 0.98 & 0.88 & 0.72 & Constant no difference \\
\hline Training spend & 1.60 & 0.76 & 0.79 & Constant no difference \\
\hline Training days & 0.85 & 0.95 & 0.77 & Constant no difference \\
\hline
\end{tabular}

Notes: ${ }^{* *} \mathrm{p}<0.01,{ }^{*} \mathrm{p}<0.05$ using robust standard errors; Effects tested under conditions of: Indigenous, CME, 2009-10. 
FIGURE 1

Effect sizes on HRM practice use

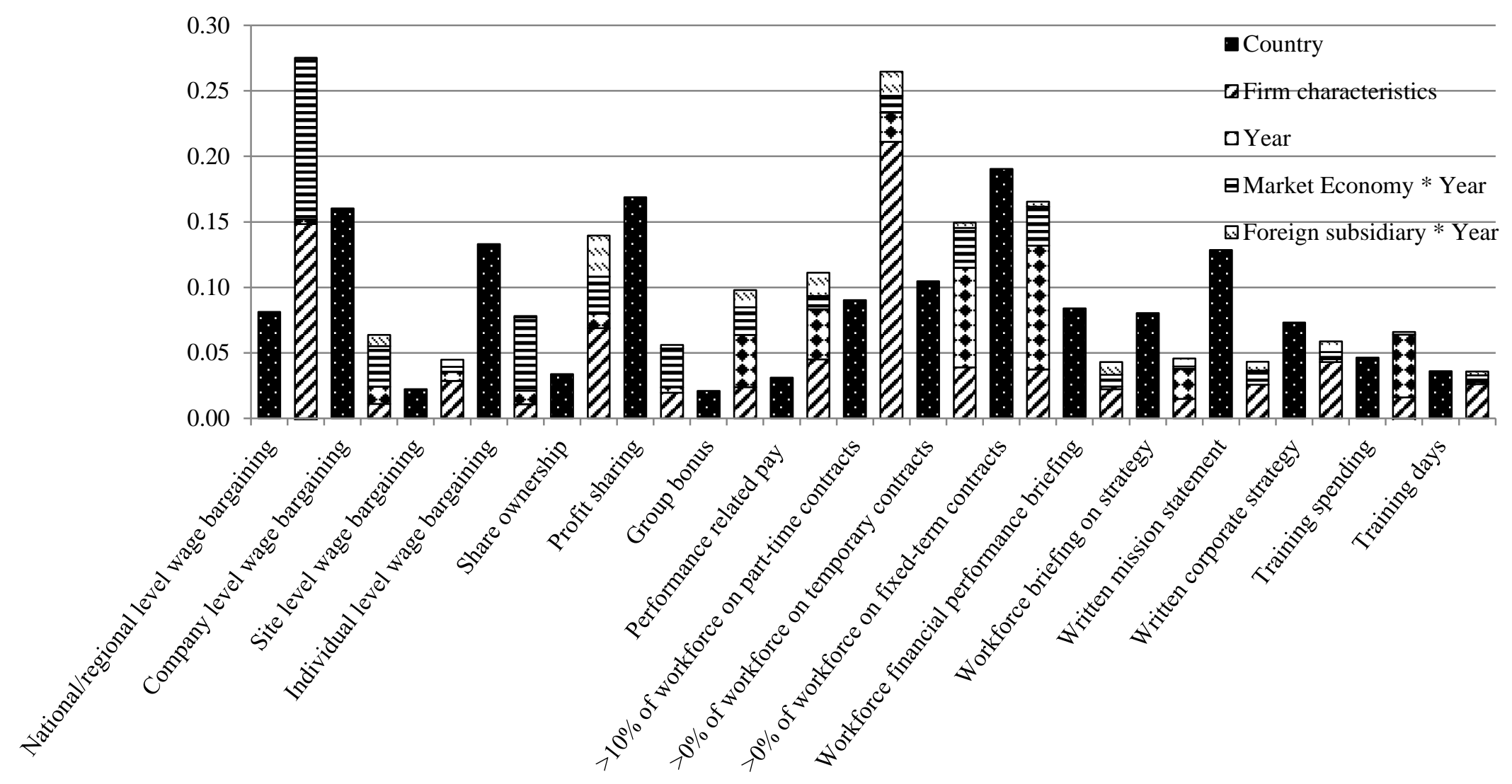

Notes: Per practice, bar 1 = level 1 (country), bar 2 = level 2 (firm characteristics, year, foreign MNE subsidiary*year, market economy*year); McKelvey-Zavoina R. The first components entered are the country (level 1) and the firm characteristics and year (level 2, main effects only), subsequently followed by foreign MNE subsidiary including year interactions, and market economy including year interactions. 